\title{
Uncertainty, informational spillovers and policy reform: A gravity model approach
}

\author{
Jan Fidrmuc ${ }^{\text {a,b,c,** }}$ and Elira Karaja ${ }^{\text {d,e }}$ \\ ${ }^{a}$ Department of Economics and Finance and CEDI, Brunel University, Uxbridge, UB8 3PH, UK. \\ ${ }^{\mathrm{b}}$ Institute of Economic Studies, Charles University, Czech Republic \\ ${ }^{\mathrm{c}}$ CESifo Munich, Germany \\ ${ }^{\mathrm{d}}$ Department of Economics and BEHL, University of California, 530 Evans Hall \#3880, Berkeley, \\ California 94720-3880, USA \\ ${ }^{\mathrm{e}}$ Institute for Research in the Social Sciences (IRiSS), Stanford University, USA
}

July 2013

\begin{abstract}
Reforms often occur in waves, seemingly cascading from country to country. We argue that such reform waves can be driven by informational spillovers: uncertainty about the outcome of reform is reduced by learning from the experience of similar countries. We motivate this hypothesis with a simple theoretical model of informational spillovers and learning, and then test it empirically using an approach inspired by the gravity model. We find evidence of informational spillovers both with respect to both political and economic liberalization. While the previous literature has focused only on economic reform, we find that the spillovers are particularly important for political changes.
\end{abstract}

Keywords: Economic reform; Democratization; Institutions; Uncertainty; Spillovers.

JEL Codes: O11; O47; P27

\footnotetext{
* Corresponding Author. Email: Jan.Fidrmuc@brunel.ac.uk or jan@fidrmuc.net. Web: http://www.fidrmuc.net/. Phone: +44-1895-266-528. We have benefited from helpful conversations with Javier Coto Martinez, Brad De Long, Chris Doucouliagos, Barry Eichengreen, Yuriy Gorodnichenko, Gérard Roland, Ariane Tichit, Arye Hillman as the editor and an anonymous referee. Elira Karaja gratefully acknowledges the research support and hospitality provided by the Economics Department, BEHL and ISEEES at UC Berkeley. Her research was partially funded by a $\mathrm{PhD}$ research fellowship granted by the Italian Ministry of Education, Universities and Research.
} 


\section{Introduction}

Political and economic changes tend to occur in waves, in a pattern sometimes described as the domino effect: changes initiated in one country spread to other countries. Examples of this phenomenon in the political domain include the events of 1848 in Europe, emergence of new independent countries from the ruins of the Ottoman and Hapsburg Empires in the late $19^{\text {th }}$ and early $20^{\text {th }}$ century, decolonization following the end of the $2^{\text {nd }}$ World War, democratizations in Latin America in the late 1980s and in Eastern Europe in the early 1990s, and most recently the so-called Arab Spring in the Middle East and the Occupy movement in Western countries. ${ }^{1}$ On the economic front, we can observe similar waves, such as the liberalization and privatization waves during the late 1980s and throughout the 1990s. Reform spillovers can be observed also with respect to less dramatic changes. The ban on smoking in restaurants and bars, adopted in Ireland in 2004, has since spread to most European countries. Eastern Europe, on the other hand, has experienced similar legislative spillovers with respect to the adoption of the flat tax, first introduced in Estonia in $1994 .^{2}$

We argue that reform waves, such as the preceding examples, are fuelled by informational spillovers. The outcome of a reform is inherently uncertain. Reversing an alreadyimplemented reform, furthermore, is costly. Uncertainty about the reform outcome combined with costly reversal may cause efficiency-enhancing reforms to be postponed or not implemented at all: a phenomenon referred to as the status-quo bias (Fernandez and Rodrik, 1991, see also Alesina and Drazen, 1991). Individuals (and governments), however, can infer important signals about the likely outcome of the reform by observing similar reforms elsewhere. If the reform turns out to have positive repercussions in one country, other countries become more likely to implement the same reform; a negative outcome in one country can stop the reform in its tracks in other countries too.

To illustrate how this phenomenon might work, we formulate a simple theoretical model of political economy of reform with inter-country informational spillovers. The model yields testable predictions which we then subject to an empirical analysis. We look at the postcommunist transitions in Central and Eastern Europe (with our data spanning the period from the beginning of reforms in these countries until the onset of the recent economic and

\footnotetext{
${ }^{1}$ Note that these reforms need not necessarily imply a change for the better. For example, the recent Arab Spring arguably has lead to an islamization rather than democratization of the affected countries.

${ }^{2}$ In both cases, the innovation originated outside Europe. The smoking ban was introduced in various US jurisdictions about a decade before its introduction in Ireland. Hong Kong, similarly, has had a flat tax for decades before its adoption in Estonia.
} 
financial crisis, i.e. 1990-2008). We consider the post-communist countries because of two reasons: (1) the vast majority of them at least attempted economic and political reforms during the period in question, and (2) this group of countries displayed a great deal of variation in the depth and outcomes of reforms implemented. While much of the literature on the relationship between reforms and uncertainty has been written with economic reforms in mind, we expect spillovers to apply to political and economic reforms alike. We thus measure reforms using indexes of democratization and economic liberalization. Our empirical findings strongly suggest that informational spillovers indeed have played a role in facilitating economic and political changes in these countries. The spillovers with respect to the latter appear particularly prominent.

In the next section, we discuss the related literature on the role of uncertainty in determining the success of reforms and on spillovers or contagion effects in reforms. In section 3 , we formulate a simple model showing how informational spillovers can reduce uncertainty and foster reforms. We then move on to our empirical analysis which is motivated by the theory. In section 4, we outline the data while in section 5 we discuss our methodology. We present our main findings in section 6 . The last section summarized the main conclusions.

\section{Related literature}

The relationship between uncertainty and reform success has been explored extensively in the literature motivated by the reforms (and their failures) in Latin America and Easter Europe during the 1980s and 1990s. Fernandez and Rodrik (1991) coined the term status-quo bias to describe the situations when countries fail to implement reforms that are expected to increase overall welfare. They argue that this is due to uncertainty about the distribution of costs and benefits of the reform. In particular, it is possible that a reform that benefits the majority of the population ex post is nonetheless rejected ex ante because, in the presence of uncertainty, the expected value of the payoff from implementing it can be negative for some voters. Alesina and Drazen (1991), similarly, show that uncertainty about the distribution of benefits and costs of reforms can lead to inefficient delays due to war of attrition. Dewatripont and Roland (1992a,b; 1995) consider aggregate rather than individual uncertainty. They point out that reforms implemented gradually rather than in a big-bang fashion are more likely to succeed because their piecemeal implementation partially resolves the underlying uncertainty about their eventual outcome. If reform reversal is costly, gradualism allows the voters to 
receive a signal about the outcome of the full reform early on. Depending on the signal, they can either continue to implement the remainder of the reform or reverse the initial reform to return to the status quo. Doing the latter avoids having to reverse the full reform, which is more costly than reversing a partial reform.

More recently, Holder (2012) formulates a model motivated by the Arab Spring process. He argues that the outcome in different countries depends on two factors: the oil wealth of the dictator, and whether the regime originates from an ethnic or religious minority group or from the majority. Accordingly, oil rich dictators who stem from the majority group will seek to avoid political change by increasing public spending (as happened in Saudi Arabia), rich minority-group governments would resist the change militarily (Libya and Syria), while poor majority dictators concede defeat (Tunisia and Egypt).

The preceding contributions consider reforms in one country in isolation from what might be going on elsewhere. ${ }^{3}$ Yet, the notion that reforms or policies in one country can affect outcomes elsewhere is not new. This process has been denoted, variously, as snowballing (Brezis and Verdier, 2003), contagion (Gassebner, Gaston and Lamla, 2008, and Campos and Horvath, 2006), and learning (Meseguer, 2006). Most of this literature, however, considers primarily economic reforms and ignores similar waves of political liberalization. A partial exception is the model by Brezis and Verdier (2003) who argue that democratization in a neighboring country makes it easier for repressed citizens to emigrate. That, in turn, reduces the ability of the dictator to repress protest and makes political liberalization there more likely too, thus opening the way for economic reform.

Gassebner et al. (2011) propose a theoretical model of reform spillovers. They argue that 'contagion' of reforms emerges because of inter-jurisdictional competition due to factor mobility as well as because of trade between countries. ${ }^{4}$ They then test their model using data on a broad panel of countries, with reform measured by the index of economic freedom (Heritage Foundation). They find that economic reforms in other countries are indeed important determinants of reform progress elsewhere and that these spillovers are better facilitated by geographic and cultural proximity than by trade.

Meseguer (2006) formulates a model in which policy makers use the experience of other countries to update their expectations on the outcome of reform in their own country through

\footnotetext{
${ }^{3}$ Holder (2012) nevertheless recognized the interconnectedness of the revolts in the Middle East by suggesting that they were set off by a 'window of opportunity' for change, without specifying what constituted this window. ${ }^{4}$ In a related paper, Faber and Gerritse (2012) consider the impact of trade and investment flows on institutional quality.
} 
a process of Bayesian learning. She tests this model empirically, with reform outcomes measured as having an independent central bank, liberal trade regime, agreement with the IMF and engaging in privatization. She finds evidence of learning in three out of the four policy areas, the exception being central bank independence. ${ }^{5}$ The analysis, however, is somewhat ad-hoc: some variables of interest are policies (i.e. stock measures) while others capture policy changes (changes/reforms of policies). Having an independent central bank and liberal trade regime are examples of the former while engaging in privatization (rather than having most productive assets in private ownership) is the latter. Having an agreement with the IMF, furthermore, does not necessarily capture reform but may reflect the underlying economic hardship that compels countries to seek assistance from the IMF.

A closely related concept to informational spillovers is political yardstick competition. The concept of yardstick competition was developed by Shleifer (1985) in the context of setting prices for regulated firms. Crucially, it was applied to elections and political processes by Salmon (1987), whose work was followed by Besley and Case (1995), Ashworth and Heyndels (1997), Wrede (2001), Bodenstein and Ursprung (2005) and others. In a nutshell, this model predicts that in the presence of asymmetric information, voters cannot easily determine whether economic outcomes (e.g. the size of budget deficit) is to be attributed to politicians' actions (effort, competence and/or ideological bias) or to objective economic circumstances (see Cukierman and Tommasi, 1998). Observing outcomes in other jurisdictions then presents a relevant benchmark (yardstick) against which to measure their own government's performance at election time.

In the remainder of the paper, we develop a simple theoretical model of informational spillovers and their impact on reforms under uncertainty. We argue that this mechanism can be at work for economic and political reforms alike. We then test the predictions of this model empirically on a sample of post-communist countries undertaking both kinds of reforms.

\section{Model of reform, uncertainty and informational spillovers}

The fundamental problem of implementing a political or economic reform is that their outcome is inherently uncertain. Attempts at political change may lead to democracy and rule of law but they can also degenerate into political instability, infighting or open political or

\footnotetext{
5 Brueckner (2000), analyzing welfare reform, similarly argues that the level of benefit provision in neighboring states affects policymakers' decision on the generosity of the welfare state.
} 
even military conflict. For example, consider two countries that experienced transition to democracy in 1989-90: Poland and Romania. Both started with broadly based and peaceful protests and both ended up with their countries undertaking extensive democratization and eventually joined the EU. The eventual trajectory and the economic and human cost involved were dramatically different, however. ${ }^{6}$ Similarly, the Tunisian and Libyan protests in 2010-11 both eventually lead to the downfalls of the incumbent regimes but at dramatically different costs. Economic reform, likewise, can bring about economic growth and rising living standards or it can give rise to unemployment and run-away inflation. The contrast, for example, between the outcomes of economic reforms in Russia and China is especially poignant.

The role of uncertainty about reforms and their outcomes has been well recognized in the early transition literature (see in particular Fernandez and Rodrik, 1991; and Dewatripont and Roland, 1992a,b and 1995). The main lesson is that uncertainty can result in efficiencyenhancing reform being postponed or abandoned altogether. Reducing uncertainty therefore is the key to the successful implementation of the reform. Dewatripont and Roland(1992a,b) show that a gradual reform leads to partial resolution of uncertainty about the outcome of the full reform. In their framework, a partial reform is never optimal alone but the cost of reversing it is lower than that of reversing the full reform. By implementing the partial reform first, voters obtain a signal about the outcome of the full reform. With this signal, and the associated reduction in uncertainty, they can make a better-informed choice whether to continue with the remaining reform measures or reverse those already implemented.

We formulate a simple three-period model which builds on Dewatripont and Roland's analysis with a crucial difference: in our framework, the resolution of uncertainty comes from observing the experience of other countries rather than from implementing the reform in a piecemeal fashion. ${ }^{7}$ In the two examples of political reforms mentioned at the beginning of this section, political transitions in Eastern Europe in the early 1990s and the Arab Spring, the changes started in Poland and Tunisia, respectively. Both countries' experience with the

\footnotetext{
${ }^{6}$ In Poland, the large-scale protests lead to a round-table negotiation between the communist government and the opposition. This, in turn, opened the way for a free election, which the opposition won overwhelmingly. The Communist Party in turn transformed itself into a successful Western-style social-democratic party (Democratic Left Aliance). The Romanian government, in contrast, sought to contain and suppress the protest by calling in the police and later the army. The ensuing armed struggle was won by the opposition after the army switched sides. The last communist president, Nicolae Ceauşescu, was executed and the communist party broke up and disappeared.

7 Besides Dewatripont and Roland, the model of neighborhood effects in Durlauf (2004) and the theory (and empirics) of political yardstick competition discussed in the preceding section are also of relevance to our model.
} 
reform was relatively smooth, certainly when compared to the subsequent events in Romania and Libya. Had the initial country experienced a great deal of bloodshed, it is very well possible that no reform wave would have taken place in either region. ${ }^{8}$

Consider country $i$ with a continuum of risk-averse individuals. We do not model the interaction between the government and citizens explicitly. Instead, we assume that the government seeks to maximize its utility (which may include ideological motives as well as private rents) subject to a political constraint. The latter is embodied in the ability of the citizens to remove the government in a democratic election or by means of a popular unrest or revolt. Economic or political reforms therefore do not occur necessarily because the government seeks to maximize overall welfare. Rather, the government is either compelled to implement a reform by the prospect of its imminent removal from office, or it is toppled and replaced by another government that undertakes the reform. The nature of the reform again reflects the political constraint, which in turn is influenced by the information set available at the time. We believe this (perhaps cynical) view is justified in the case of post-communist and developing countries: reforms tend to be implemented in the wake of political upheavals and often end up captured by interest groups who use them to further their own objectives (Hellman, 1998).

In line with the preceding discussion, we therefore focus on the nature of the political constraints and, specifically, on the preferences of the citizens. The agents can be heterogeneous but, as Dewatripont and Roland, we only consider uncertainty about aggregate outcomes common to all. The status quo is associated with a negative payoff; the period value of that payoff is $-\gamma_{i}$. This disutility can stem either from economic policies or from political repression in the status quo. For example, depending on context, the status quo can correspond to excessive state interference in the economy, distortionary taxes, tolerance of smoking in public places, or disregard for political rights of individuals. The status quo can be amended by implementing a reform. The outcome of that reform, however, is uncertain, and may even be worse than the status quo. Based on the information available before the reform, the agents form expectations about the period value of the reform's outcome. Let $\mathrm{E}\left(\omega_{\mathrm{i}} \mid I_{i}\right)$ be the expected value of the future payoff, $\omega_{\mathrm{i}}$, conditional on the information available at present, $I_{i}$. For simplicity, we assume that the same payoff will accrue in every period after the implementation of the reform unless the reform is reversed; we therefore omit time indexes. If

\footnotetext{
${ }^{8}$ Similarly, the Hungarian Revolution of 1956 and the Prague Spring in Czechoslovakia in 1968, both of which were crushed by Soviet invasions, did not set off waves of similar events elsewhere.
} 
the outcome of the reform is worse than the status quo, the reform can be reversed in the third period; the reversal is associated with $\cos t-\xi_{i .}{ }^{9}$ The decision whether to maintain the reform or reverse it is taken at the end of the first period, after the payoff for that period is revealed (and incurred). If the reform is reversed, the reversal cost is incurred and thereafter the statusquo payoff is again restored. For simplicity, we assume that the status quo payoff and reversal costs are not uncertain.

Assuming no informational spillovers (autarky), the return from implementing the reform will be

$$
\mathrm{E}\left(\omega_{\mathrm{i}} \mid \mathrm{I}_{i}\right)+\delta \mathrm{E}\left(\omega_{\mathrm{i}} \mid \mathrm{I}_{i}\right)+\delta^{2} \mathrm{E}\left(\omega_{\mathrm{i}} \mid \mathrm{I}_{i}\right)
$$

in case the reform is maintained, and

$$
\mathrm{E}\left(\omega_{\mathrm{i}} \mid \mathrm{I}_{i}\right)-\delta \xi_{i}-\delta^{2} \gamma_{i}
$$

if it is reversed. The payoffs that accrue during the second and third periods are discounted by a discount factor $\delta$.

The reform therefore will be implemented if

$$
\mathrm{E}\left(\omega_{\mathrm{i}} \mid \mathrm{I}_{i}\right)>-\gamma_{i}
$$

where $I_{i}$ is stands for all the information available in country $i$ during the first period. The reform will be maintained if

$$
\omega_{\mathrm{i}}+\delta \omega_{\mathrm{i}}>-\xi_{i}-\delta \gamma_{i}
$$

Note that the decision whether to maintain or reverse the reform is based on the actual outcome, revealed once the reform has been implemented, rather than its expectation.

Now we consider the case with informational spillovers. We assume that the outcomes of reforms implemented elsewhere can be observed with a lag of one period. Therefore, the agents in country $i$ have an additional option: to postpone implementing the reform in order to observe its outcome in countries that have already implemented it. In that case, the information set available in country $i$ is $[\Omega, X] . \Omega$ is the vector of the actual outcomes in other countries, $\omega_{1}, \ldots, \omega_{\mathrm{n}}$ while $\mathrm{X}$ is a vector of parameters $\chi_{1}, \ldots, \chi_{\mathrm{n}}$ depicting how similar the conditions in the various other countries are to the conditions in country $i$. This strategy therefore yields the payoff

\footnotetext{
${ }^{9}$ The payoff of implementing the reform and the reversal costs can incorporate also external factors such as the economic support received from the World Bank and other international financial institutions (as well as the conditionality associated with such support), the prospect of EU membership, and the like.
} 


$$
-\gamma_{i}+\delta \mathrm{E}\left(\omega_{\mathrm{i}} \mid \Omega, \mathrm{X}\right)+\delta^{2} \mathrm{E}\left(\omega_{\mathrm{i}} \mid \Omega, \mathrm{X}\right)
$$

in case the reform is maintained, and

$$
-\gamma_{i}+\delta \mathrm{E}\left(\omega_{\mathrm{i}} \mid \Omega, \mathrm{X}\right)-\delta^{2} \xi_{i}
$$

if it is reversed. The conditions for maintaining or reversing the reform are similar as before except that now this decision takes place at the end of the second rather than the first period.

Postponing the reform is costly: it results in the negative status-quo payoff being incurred for one additional period. This is captured by the first term in the payoff functions (5) and (6). The cost of doing so, however, may be outweighed by the benefit of improving the precision of the expectation of the reform's outcome in the next two periods. If the informational spillovers from the other countries are significant, they help avoid the potential additional cost of having to reverse a reform whose outcome is worse than the status quo.

This result is similar to that of Dewatripont and Roland (1992a,b) who argue that gradual reform helps reduce uncertainty about the outcome. In this case, the reduction of uncertainty stems not from the reform being implemented gradually but from postponing it and learning from the experience of others. Once the outcomes of reforms implemented elsewhere are observed, the reform can be implemented in a big-bang fashion. However, this strategy can be optimal only if the cost of maintaining the status quo for one additional period is not very high.

Informational spillovers such as those discussed in the model above are likely to be one reason why political or economic changes occur in waves, as was the case in the postcommunist countries during 1989-91 or in the Middle East during 2011. For example, the decision of Polish and Hungarian communist governments not to suppress the popular protests and then to engage in negotiations with the opposition in the spring and summer of 1989 was likely to have been instrumental in encouraging the subsequent protests in East Germany and Czechoslovakia in fall of that year. Had either Polish or Hungarian government chosen to crack down on the protests as later happened in Romania, the enthusiasm for political change may well have waned throughout the region. Similarly, the positive outcome and the relatively low cost of political change in Tunisia in the spring of 2011 is likely to have encouraged the protests to be replicated throughout the Middle East. It is also not surprising that the remaining authoritarian regimes, such as North Korea and China, have sought to 
suppress the spread of information about the changes in the Middle East. ${ }^{10}$

Similarly, the countries that initiated economic reforms relatively late benefited from the experience of Poland and Hungary whose reforms started in 1990. The (predominantly negative) experience with partial economic reforms in the former Yugoslavia in the course of the 1980s also could have had informational value: it may have contributed to the decision of the subsequent reformers to shy away from piecemeal reform.

Last but not least, the experience of other countries can help also with respect to selecting the toolkit for facilitating change. The use of text messages and social networks to organize political protests in Iran in the wake of the 2009 election was replicated throughout the Middle East in 2011 and is likely to have contributed to the success of those movements. ${ }^{11}$

We therefore hypothesize, in line with our model, that the progress in political and economic reform should be related to the stock of similar reforms implemented previously in other countries. ${ }^{12}$ The intensity of informational spillovers, furthermore, is also likely to depend on the extent the two countries are similar: we expect the spillovers to be higher for geographically as well as culturally close countries.

We test these predictions on a sample of post-communist counties during the 1990s and 2000s. We focus on these countries because virtually all of them at least attempted to implement economic and political reforms during this period. The reform strategies as well as their outcomes, however, differed substantially across countries. This sample thus offers sufficient variation in reform progress, both in the economic and political domains.

Flows of information between two countries, of course, are difficult if not impossible to observe. Instead, we can utilize either outcomes (such as inflation, unemployment or growth) or actual policies. We choose the latter even though our model is formulated with outcomes in mind, as qualitative assessment of outcomes of economic or political reforms is context

\footnotetext{
10 The government of North Korea was reported to have banned its citizens who worked in Libya under the Qaddafi regime from returning (see "North Korea bans citizens working in Libya from returning home," The Telegraph, 27 October 2011. China regularly suppresses news about popular protests in its media, regardless of whether those protests take place in China or elsewhere. Websites such as Facebook and Twitter, which helped coordinate protest in the Middle East and elsewhere, have been blocked in China. Finally, it is particularly instructive to compare the results of searching for keywords such as 'Jasmine revolution' on google.com and baidu.com: the two alternative search engines produce dramatically different lists of entries.

11 The Chinese government has learned this lesson too. During the 2009 unrest in Xinjiang, mobile-phone and internet services remained suspended for extended periods in the province.

12 Importantly, the reform concerned can represent either an improvement or worsening of the status-quo: informational spillovers can foster an extension of human rights or economic liberalization or the opposite processes.
} 
dependent. Inflation and unemployment immediately in the wake of liberalization can be a sign of the reform being successful, while in a different context they can symbolize failure. Similarly, absence of political protest can indicate expansion of political freedoms and democracy, or intensification of repression.

\section{Data}

Our analysis considers political and economic reforms that started in the post-communist countries of Eastern Europe and the former Soviet Union in the early 1990s. ${ }^{13}$ While some countries implemented wide-ranging reforms relatively quickly, others proceeded more gradually and/or experienced set-backs and reform reversals. Correspondingly, our data cover the years 1990 to 2008 . We use 2008 as the cut-off year to ensure that we capture the reform period but avoid including the current economic and financial crisis. We only consider spillovers among the post-communist countries and thus ignore the rest of the world. This is due to the fact that the experience of countries with similar starting position and undergoing similar changes is likely to be more relevant than the experience of established democracies and market economies.

To capture the countries' progress in implementing market-oriented policies, we use the average of eight progress-in-transition indicator compiled and published annually by the European Bank for Reconstruction and Development (EBRD). ${ }^{14}$ We use the average Freedom House democracy index ${ }^{15}$ to take account of the progress in democratization. Finally, we identify periods of war using the Correlates of War (2010) dataset.

\footnotetext{
${ }^{13}$ We include Albania, Armenia, Azerbaijan, Belarus, Bosnia-Herzegovina, Bulgaria, Croatia, Czech Republic, Estonia, Georgia, Hungary, Kazakhstan, Kyrgyzstan, Latvia, Lithuania, Macedonia, Moldova, Mongolia, Monte Negro, Poland, Romania, Russia, Serbia, Slovakia, Slovenia, Tajikistan, Turkmenistan, Ukraine and Uzbekistan.

14 These indicators measure each country's progress in the following fields: price liberalization, foreign exchange and trade liberalization, small scale privatization, large scale privatization, enterprise reform, competition policy, banking reform, and security markets and non-banking financial institutions. Each indicators ranges from 1 (unreformed centrally-planned economy) to 4+ (liberal market economy). As is common in this literature, we replace plus and minus distinctions by adding and subtracting 0.33 (so that $4+$ becomes 4.33 while 4 - is 3.67). We do not use the more recently available EBRD indicators of infrastructure reform, only the eight original indicators measuring progress in Washington-consensus reform (liberalization, stabilization and privatization).

${ }^{15}$ Specifically, this index is the average of the Freedom House measures of political freedoms and civil liberties, rescaled so that higher values correspond to more democracy. It ranges between 1 (autocracy) to 7 (fully free).
} 


\section{Methodology}

Our theoretical model predicts the existence of informational spillovers with respect to policy reform and also that these should decline with the distance between countries. The distance, furthermore, can be interpreted as not only the geographic distance but also as cultural proximity and/or common historical legacies. In order to take account of this, our analytical approach combines two well know empirical models: the spatiotemporal autoregressive model (STAR) and the gravity model. We start by describing the latter and then discuss how our approach compares to the former.

The gravity model (see Baldwin and Taglioni, 2006, and the references therein) is widely applied in the international trade literature, where it is used to explain bilateral trade flows between pairs of countries (later applications use it also to analyze foreign direct investment and migration flows). It takes its inspiration from the theory of gravity in physics, where the force of gravity between two objects is defined as: ${ }^{16}$

$$
F_{i j}=G \frac{M_{i} M_{j}}{D_{i j}{ }^{2}}
$$

The force of gravity, $F$, between objects $i$ and $j$ is thus proportional to their masses, $M_{i}$ and $M_{j}$, the gravitational constant, $G$, and inversely proportional to the square of distance between them, $D_{i j}$. Applied to the study of economic phenomena, the gravity model takes the following form (omitting time subscripts for simplicity):

$$
F_{i j}=\mathrm{A} \frac{Y_{i} Y_{j}}{\left(D_{i j} c u l t_{i j}\right)^{2}}
$$

where $F_{i j}$ stands for the economic flow (such as trade or migration) between two countries, $i$ and $j, Y_{i}$ is the economic equivalent of physical mass of country $i$ (in the context of trade and migration, mass can be proxied by total GDP and population, respectively), $A$ is an arbitrary constant term, and, finally, the denominator collects the various distance terms, such as geographic and cultural distance.

In our analysis, we wish to capture the flow of information about the outcome of policy reform between countries. The gravity relation (now with the time subscripts added back) therefore can be rewritten as follows:

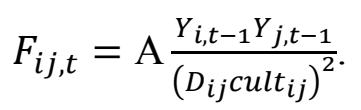

\footnotetext{
16 This follows Baldwin and Taglioni (2006).
} 
$F_{i j, t}$ now stands for the informational flow or spillovers from country $j$ to country $i$ at time $t$. This depends on the stock of policies implemented in both countries in the preceding period, $t-1$. Specifically, in line with our theoretical model, we expect the informational spillover to be proportional to the stock of policies in country $j$ and inversely proportional to the distance between them.

Unfortunately, we do not observe the actual informational spillovers from country $j$ to country $i$. Instead, we only observe the actual progress in policy reform in $i$ that results, in part, from these spillovers:

$$
\dot{Y}_{i, t}=f\left[F_{1, j, t}\left(Y_{1, t-1}\right), F_{2, j, t}\left(Y_{2, t-1}\right) \ldots F_{n-1, j, t}\left(Y_{n-1, t-1}\right)\right]
$$

That is, we observe the policy change in country $i$ in period $t$, which is a function of the unobserved (latent) informational spillovers from the remaining $n-1$ countries. We also know that each of those spillovers is itself a function of the country's own policies. ${ }^{17}$ Thus, we approximate the gravity relation in equation (9) by

$$
\dot{Y}_{i, t}=\mathrm{A} \frac{Y_{i, t-1} Y_{j, t-1}}{\left(D_{i j} \text { cult }_{i j}\right)^{2}}
$$

In other words, we assume that the progress in policy reform in country $i$ is proportional to the lagged policies in $i$ and $j$ and inversely proportional to the distance (geographic, cultural and historical) between $i$ and $j$. Linearizing this relation by taking logs of both sides and using lower case letters to denote logs, we get

$$
\Delta y_{i, t}=\alpha+\beta_{1} y_{i, t-1}+\beta_{2} y_{j, t-1}+\beta_{3}{ }^{*} d_{i j}+\beta_{4}{ }^{*} \text { contiguity }_{i j}+\beta_{5}{ }^{*} \text { samecountry }_{i j} .
$$

The dependent variable is the log-difference in the index of policies (see below) in country $i$ during period $t$. We consider three measures of distance/proximity: geographical distance, common-border dummy and a dummy for belonging to the same country in the past (former Soviet Union, Yugoslavia and Czechoslovakia). Clearly, sharing common border or having common history should make the flow of information easier. We further augment this equation to include interactions between distance and reforms, to allow for the effect of reform in country $j$ to vary with distance, and, finally, add dummies to account for military conflicts and country and year fixed effects. Our baseline regression becomes

$$
\Delta y_{i, t}=\alpha+\beta_{1} y_{i, t-1}+\beta_{2} y_{j, t-1}+\beta_{3} * d_{i j}+\beta_{4}{ }^{*} \text { contiguity }_{i j}+\beta_{5} * \text { samecountry }_{i j}
$$

\footnotetext{
17 In line with our model, we assume that the informational spillover occurs with a lag rather than contemporaneously. Therefore, we do not need to consider the possibility of simultaneous determination of policies in $i$ and $j$.
} 


$$
\begin{aligned}
& +\beta_{6} y_{j, t-1} * d_{i j}+\beta_{7 y_{j, t-1}} * \text { contiguity }{ }_{i j}+\beta_{8 y_{j, t-1}} * \text { samecountry }_{i j} \\
& +\beta_{9} \text { war }_{i t}+\beta_{10} \text { war }_{j t}+\eta_{i}+v_{t}+\varepsilon_{i t} .
\end{aligned}
$$

The first row collects the standard gravity variables: indexes of policies in countries $i$ and $j$, and the various distance measures. The second row collects the interaction terms between the policy index in country $j$ and the distance terms. The terms in the second row are similar to the spatial lags used in the STAR (spatiotemporal autoregressive) model. That model is used for analyses involving regional (geographic) data that are thought to display correlation of residuals among adjacent or nearby regions (this correlation can be contemporaneous or involve temporal lags). ${ }^{18}$ There are several differences between our model and the STAR model.

First, the STAR model regresses the outcome of interest on the sum (or average) of all spatial lags. In contrast, we introduce spatial lags for each pair of countries separately. This means that the information pertaining to each pair is being considered and the effects of individual counterpart countries therefore cannot cancel out. ${ }^{19}$ In other words, our specification is more disaggregated than the typical STAR model.

Second, our approach is more flexible in that it allows us to consider spillovers from adjacent as well as distant regions, it facilitates the use of multiple distance measures (geographical distance, contiguity and common history in our case), and it is consistent with countries having different numbers of neighbors. The STAR model, in contrast, typically allows for only one type of spillover at a time, such as from contiguous regions, weighted by geographical distance or from regions that are culturally or linguistically close (see, for example, Table 3 in Becker et al., 2009). In case of contiguity, furthermore, it is common to normalize the sum of weights of all neighboring regions to unity so that the impact of a particular region on another depends on the number of other contiguous regions that the region in question has.

Third, a potentially important drawback of the STAR model is that it introduces spatial lags (interactions between the variables of interest and the various distance measures used as weights) without also including the distance terms on their own. Finding, for example, that the spatial lag weighed by distance is negative may be driven by the fact that policies in other

\footnotetext{
18 Recent applications of this model in economics are Becker, Egger and Seidel (2009) and Bartz and FuchsSchündeln (2012). See also the overview in Durlauf (2004).

${ }^{19}$ For example, taking the average spatial lag would imply that a combination of a high-reform and low-reform country has the same effect as two countries with intermediate reform. The advantage of considering individual realizations rather than their average would be even stronger when considering non-linear effects.
} 
countries have a negative effect in general, without taking account of distance, that countries that are relatively remote implement less reform, or that the effect of other countries' policies declines with distance. Without including the original terms as well as the interactions, these three possible explanations cannot be disentangled.

A specific feature of our analysis is that although we consider all possible pairs of countries, we only observe the change of policies in each country and year rather than the actual informational spillover between the two countries. This implies that while we have 12-13 thousand pairs of countries, we only have 580 unique observations of the reform progress (29 countries and 20 years). OLS, therefore, would estimate the standard errors incorrectly (biased downwards). We therefore present regression results obtained with cluster-robust standard errors, with country-year combinations set as primary sampling units.

Note, finally, that we carry out our analysis with policy indexes rather than with outcomes such as growth or inflation rates. Policy indexes assess whether particular policies were put in place. Implementing policy reform may be associated with an initial cost (temporary worsening of economic performance) followed by a subsequent improvement. For example, moderate inflation following a policy of price liberalization may be judged a success if the alternative outcome is run-away hyperinflation. Similarly, a recession in the wake of fiscal stabilization may be superior to a failed stabilization resulting in a sovereign default and a much deeper contraction.

\section{Results}

We consider two types of reform: economic and political one. The dependent variable is the log-difference (unless specified otherwise) of the respective index: economic reform or democracy. We account for distance using three different measures: actual geographic distance, dummy for contiguity (having a common land border between two countries), and having common history (being part of the same country, i.e. the former Soviet Union, Yugoslavia and Czechoslovakia). We first introduce each distance measure on its own and then also run a regression with all three measures at the same time. We always enter the distance measure directly as well as interacted with the index of reform in country $j$.

The results for democratization are summarized in Table 1 while those for economic liberalization are in Table 2. Columns (1) through (3) of each table present the results of estimating equation (13) with one distance measure at a time. Column (4), in turn, features all 
three distance measures as well as the corresponding interaction terms. Overall, the results show strong support for our theoretical prediction in case of democratization and somewhat weaker support in case of economic liberalization. The lagged level of the reform index in country $j$ is not consistently positive, indicating that spillovers, if any, indeed depend on distance. The coefficient for geographical distance (on its own, not interacted with a policy index) is negative, significantly so in the regressions for democracy. This can be interpreted as suggesting that countries that are relatively remote (i.e. those that are far from other countries in the sample) tend to reform their policies more slowly. The interaction between geographical distance and either reform index is negative, again significantly when we consider democracy: the impact of political liberalization in other countries declines with distance. The common border dummy is positive and significant in the regression for democracy while the same-country dummy is positive and significant for either index. Hence, countries that share borders or historical legacies with other countries tend to reform faster, especially with respect to democratization. This is similar to the negative effect of distance: countries that are relatively distant (geographically or culturally) tend to experience fewer spillovers than other countries. The interactions with the policy indexes reinforce this effect further: the spillovers in terms of political liberalization increase both with common border and common history, while only the latter appears important for economic liberalization.

Looking at the remaining variables, the lagged level of either index in country $i$ is always strongly significant and has a negative effect on further progress. This stems from the fact that both indexes are bound from above. Therefore, countries that have already achieved a relatively high degree of economic or political freedom can only experience incremental further progress. The effect of war in country $i$ is negative and always very strongly significant: countries at war tend to postpone reform. In contrast, war in country $j$ seems to matter little.

One potential problem with our regression results is that it may be subject to a dynamic bias (Nickell, 1981). ${ }^{20}$ This is because the regression equation includes also the lagged own-reform index, $y_{i, t-1}$, which features in the definition of the dependent variable, $\Delta y_{i, t}=y_{i, t-y_{i, t-1}}$. Given that our goal is to identify the reform spillovers from other countries, the lagged own-reform index is not of particular importance for our analysis (we include mainly for methodical consistency). It is nevertheless possible that the coefficient of $y_{i, t-1}$ is biased. In column (5) of both tables, therefore, we seek to address this problem by estimating the regression using the

${ }^{20}$ We are grateful to an anonymous referee for pointing this out. 
generalized method of moments (GMM), with the second lag of the same index serving as the excluded instrument for the lagged own-reform index. The regression results are very similar to those in the preceding columns. The Hansen J statistic, however, suggests that the second lag of the relevant index cannot be excluded from the main regression equation. This is not surprising, given that both indexes are highly persistent over time and bound from above and below. However, our effort to find better instruments proved futile. ${ }^{21}$ Therefore, in column (6), we re-estimate equation (13) while omitting the lagged own-reform term, $y_{i, t-1}$, and in column (7) we estimate an alternative model with the level of the reform index, $y_{i, t}$, as the dependent variable while omitting the lagged index, $y_{i, t-1}$. Both of these are restricted versions of our original model, as captured by equation (13), and both are by construction free of the dynamic bias. Again, the regression results are broadly similar to those in the preceding columns, suggesting the presence of spillovers in economic and political reform which depend on distance.

\section{Conclusions}

We address the question of what drives the apparent waves of political and economic changes that have been observed repeatedly throughout history. We argue that these waves reflect learning and resolution of uncertainty about the outcome of political and economic reforms, a phenomenon which we denote informational spillovers. Observing the outcome of reforms implemented elsewhere reduces uncertainty and helps voters and policy makers make betterinformed decisions. In this way, a successfully executed reform in one country increases the probability that other countries follow suit. Conversely, a reform effort that played out badly in one country would discourage similar reforms elsewhere.

To illustrate this mechanism, we first formulate a simple model of reform spillovers. The model demonstrates that countries can reduce uncertainty about the reform outcome by observing the experience of other countries that implemented the same or similar reform earlier. This in turn should help reduce the status-quo bias highlighted in the previous literature.

We test our model's predictions on a sample of countries that implemented political and economic reforms during the 1990s and 2000s: the formerly communist countries in Central

\footnotetext{
${ }^{21}$ We tried a quadratic polynomial of the time since the post-communist transition began (allowing different starting dates for different countries), as well as various measures of initial conditions interacted with this time index. As with the second lag of the reform index, the Hansen J statistic rejects these instruments.
} 
and Eastern Europe. Since measuring the flow of information between two countries is difficult if not impossible, we instead relate progress in reform (political and economic alike) in one country to reforms implemented in other countries previously, and the distance to those countries. We find strong support for the presence of spillovers in reform, especially when considering democratization. We also confirm spillovers in economic liberalization, although here the results are somewhat weaker and less clear-cut. Our findings are thus in line with those of Meseguer (2006) and Gassebner et al. (2011), who find spillovers with respect to economic reform, Kelejian et al. (2013) and Faber and Gerritse (2012) whose analyses confirms spillovers in institutional development or Becker et al. (2009) who find them with respect to corruption. We believe nonetheless that we are the first to consider political changes. Interestingly, given the predominant emphasis on economic reform in the previous literature, our results suggest that spillovers are even more important in the political domain than with respect to economic policies.

Our findings suggest that the experience of other countries plays an important role in mobilizing support and maintaining the momentum for reform. The fact that spillovers appear especially important with respect to political reform should not come as surprising. The success of political reform crucially hinges on the ability of the reformers to garner and maintain popular support for their cause. This is a standard collective action problem: while many would benefit from changes, few are willing to risk life and limb to make change happen if the outcome is highly uncertain. Observing successful democratizations in other countries helps reduce the uncertainty about the eventual outcome and thus reduces the underlying collective action problem. The recent events in the Middle East demonstrate this very clearly. Learning from the experience of others thus is an important way of breaking the status-quo bias.

Besides informational spillovers, other external factors can play an important role too. The World Bank, European Bank for Reconstruction and Development and the International Monetary Fund encouraged economic reforms in the post-communist countries by making participation in their programs conditional on satisfactory performance in economic policy making. The prospect of European Union membership, likewise, served as an important external driver of economic and political changes. Such external factors can complement and strengthen the role played by informational spillovers.

An important contribution of our paper, in our view, is that we analyze neighborhood and local effects in the context of a gravity model rather than the more commonly used spatial 
autoregressive model. Using the gravity model allows us to consider bilateral relationships between countries and to account for multiple types of distance (geography and contiguity and culture). It also makes it possible to consider whether the effect of other countries' or regions' characteristics depends on distance. In other words, we account for local effects with three or more terms (the other country's characteristic, distance or multiple distance measures, and the various interaction terms) where the spatial model would use only one (spatial lag weighted by distance: geography or contiguity or culture). While the spatial model has proven very useful in the past, we believe it is important to provide an alternative. 
Table 1 Spillovers with respect to Democratization

\begin{tabular}{|c|c|c|c|c|c|c|c|}
\hline & (1) & (2) & (3) & (4) & (5) & (6) & (7) \\
\hline & $\Delta \mathrm{y}_{\mathrm{i}, \mathrm{t}}$ & $\Delta \mathrm{y}_{\mathrm{i}, \mathrm{t}}$ & $\Delta \mathrm{y}_{\mathrm{i}, \mathrm{t}}$ & $\Delta \mathrm{y}_{\mathrm{i}, \mathrm{t}}$ & $\Delta \mathrm{y}_{\mathrm{i}, \mathrm{t}}$ & $\Delta \mathrm{y}_{\mathrm{i}, \mathrm{t}}$ & $\mathrm{y}_{\mathrm{i}, \mathrm{t}}$ \\
\hline $\mathrm{y}_{\mathrm{i}, \mathrm{t}-1}$ & $\begin{array}{r}-.2967 * * * \\
(.0556)\end{array}$ & $\begin{array}{r}-.2962 * * * \\
(.0556)\end{array}$ & $\begin{array}{r}-.2961 * * * \\
(.0555)\end{array}$ & $\begin{array}{r}-.29689 * * * \\
(.05560)\end{array}$ & $\begin{array}{r}-.25492 * * * \\
(.00929)\end{array}$ & & \\
\hline $\mathrm{y}_{\mathrm{j}, \mathrm{t}-1}$ & $\begin{array}{r}.0786 * * * \\
(.0270)\end{array}$ & $\begin{array}{r}-.0020 * * \\
(.0010)\end{array}$ & $\begin{array}{r}-.0014^{*} \\
(.0007)\end{array}$ & $\begin{array}{l}.06278^{*} \\
(.03518)\end{array}$ & $\begin{array}{r}-.00890 \\
(.02644)\end{array}$ & $\begin{array}{r}.00174 \\
(.03953)\end{array}$ & $\begin{array}{r}.22594 * * * \\
(.08303)\end{array}$ \\
\hline Distance & $\begin{array}{r}-.0079 * * * \\
(.0029)\end{array}$ & & & $\begin{array}{r}-.00709 * * \\
(.00366)\end{array}$ & $\begin{array}{r}.00037 \\
(.00302)\end{array}$ & $\begin{array}{r}.00144 \\
(.00438)\end{array}$ & $\begin{array}{r}-.02965 * * * \\
(.00854)\end{array}$ \\
\hline Contiguity & & $\begin{array}{r}.0105^{* *} \\
(.0046)\end{array}$ & & $\begin{array}{r}.00002 \\
(.00573)\end{array}$ & $\begin{array}{r}.00729 \\
(.00648)\end{array}$ & $\begin{array}{c}-.00848 \\
(.00596)\end{array}$ & $\begin{array}{r}.01616 \\
(.01062)\end{array}$ \\
\hline Same country & & & $\begin{array}{r}.0183 * * * \\
(.0072)\end{array}$ & $\begin{array}{r}.00833 \\
(.00740)\end{array}$ & $\begin{array}{r}.00896 \\
(.00742)\end{array}$ & $\begin{array}{r}.00749 \\
(.00817)\end{array}$ & $\begin{array}{r}-.00057 \\
(.01307)\end{array}$ \\
\hline $\mathrm{y}_{\mathrm{j}, \mathrm{t}-1} * \operatorname{dist}_{\mathrm{ij}}$ & $\begin{array}{r}-.0106 * * * \\
(.0037)\end{array}$ & & & $\begin{array}{r}-.00859 * \\
(.00463)\end{array}$ & $\begin{array}{r}.00090 \\
(.00341)\end{array}$ & $\begin{array}{r}.00041 \\
(.00527)\end{array}$ & $\begin{array}{r}-.032212 * * * \\
(.01095)\end{array}$ \\
\hline $\mathrm{y}_{\mathrm{j}, \mathrm{t}-1}{ }^{*}$ contiguity & & $\begin{array}{r}.0149 * * \\
(.0066)\end{array}$ & & $\begin{array}{r}-.00039 \\
(.00885)\end{array}$ & $\begin{array}{l}.01270^{*} \\
(.00765)\end{array}$ & $\begin{array}{r}-.01480 \\
(.00905)\end{array}$ & $\begin{array}{l}.02966^{*} \\
(.01646)\end{array}$ \\
\hline $\mathrm{y}_{\mathrm{j}, \mathrm{t}-1} *$ smcntry & & & $\begin{array}{r}.0359 * * * \\
(.0141)\end{array}$ & $\begin{array}{r}.02285 \\
(.01448)\end{array}$ & $\begin{array}{r}.01733 \\
(.01143)\end{array}$ & $\begin{array}{r}.01377 \\
(.01616)\end{array}$ & $\begin{array}{r}.02370 \\
(.02340)\end{array}$ \\
\hline War i & $\begin{array}{r}-.1837 * * * \\
(.0673)\end{array}$ & $\begin{array}{r}-.1832 * * * \\
(.0673)\end{array}$ & $\begin{array}{r}-.1832 * * * \\
(.0673)\end{array}$ & $\begin{array}{r}-.18350 * * * \\
(.06725)\end{array}$ & $\begin{array}{r}-.20001 * * * \\
(.01368)\end{array}$ & $\begin{array}{r}-.13394 * \\
(.07417)\end{array}$ & $\begin{array}{r}-.29328 * * * \\
(.08293)\end{array}$ \\
\hline War j & $\begin{array}{r}.0012 \\
(.0016)\end{array}$ & $\begin{array}{r}-.0001 \\
(.0015)\end{array}$ & $\begin{array}{r}.0019 \\
(.0017)\end{array}$ & $\begin{array}{r}.00241 \\
(.00178)\end{array}$ & $\begin{array}{r}.00158 \\
(.00959)\end{array}$ & $\begin{array}{r}.00183 \\
(.00205)\end{array}$ & $\begin{array}{r}.00286 \\
(.00265)\end{array}$ \\
\hline Constant & $\begin{array}{r}.3469 * * * \\
(.0906) \\
\end{array}$ & $\begin{array}{r}.2890 * * * \\
(.0899) \\
\end{array}$ & $\begin{array}{r}.2903 * * * \\
(.0900) \\
\end{array}$ & $\begin{array}{r}.34061 * * * \\
(.08990) \\
\end{array}$ & $\begin{array}{r}-.12927 * * * \\
(.02286) \\
\end{array}$ & $\begin{array}{r}.63168 * * * \\
(.11409) \\
\end{array}$ & $\begin{array}{r}-.56426 * * * \\
(.17851) \\
\end{array}$ \\
\hline $\mathrm{R}^{2}$ & 0.4477 & 0.4473 & 0.4475 & 0.4478 & 0.3352 & 0.2901 & 0.7643 \\
\hline Observations & 13,107 & 13,107 & 13,107 & 13,107 & 12,375 & 13,107 & 13,257 \\
\hline PSUs & 580 & 580 & 580 & 580 & & 580 & 580 \\
\hline Countries & 29 & 29 & 29 & 29 & & 29 & 29 \\
\hline Years & 20 & 20 & 20 & 20 & & 20 & 20 \\
\hline Country_FE & $\mathrm{Y}$ & $\mathrm{Y}$ & $\mathrm{Y}$ & $\mathrm{Y}$ & $\mathrm{Y}$ & $\mathrm{Y}$ & $\mathrm{Y}$ \\
\hline Year_FE & $\mathrm{Y}$ & $\mathrm{Y}$ & $\mathrm{Y}$ & $\mathrm{Y}$ & $\mathrm{Y}$ & $\mathrm{Y}$ & $\mathrm{Y}$ \\
\hline Method & OLS & OLS & OLS & OLS & $2 \mathrm{SLS}$ & OLS & OLS \\
\hline
\end{tabular}


Table 2 Spillovers with respect to Economic Reform

\begin{tabular}{|c|c|c|c|c|c|c|c|}
\hline & (1) & (2) & (3) & (4) & (5) & (6) & (7) \\
\hline & $\Delta \mathrm{y}_{\mathrm{i}, \mathrm{t}}$ & $\Delta \mathrm{y}_{\mathrm{i}, \mathrm{t}}$ & $\Delta \mathrm{y}_{\mathrm{i}, \mathrm{t}:}$ & $\Delta \mathrm{y}_{\mathrm{i}, \mathrm{t}}$ & $\Delta \mathrm{y}_{\mathrm{i}, \mathrm{t}}$ & $\Delta \mathrm{y}_{\mathrm{i}, \mathrm{t}}$ & $\mathrm{y}_{\mathrm{i}, \mathrm{t}}$ \\
\hline \multirow[t]{2}{*}{$y_{i, t-1}$} & $-.3990 * * *$ & $-.3991 * * *$ & $-.3982 * * *$ & $-.39755^{* * *}$ & $-.44215 * * *$ & & \\
\hline & $(.0473)$ & $(.0471)$ & $(.0471)$ & $(.04694)$ & $(.01087)$ & & \\
\hline \multirow[t]{2}{*}{$\mathrm{y}_{\mathrm{j}, \mathrm{t}-1}$} & .0310 & .0022 & -.0008 & .02393 & .03452 & $.118678 * *$ & $-.23029 * * *$ \\
\hline & $(.0259)$ & $(.0016)$ & $(.0006)$ & $(.04229)$ & $(.02652)$ & $(.05473)$ & $(.06976)$ \\
\hline \multirow[t]{2}{*}{ Distance } & -.0029 & & & -.00318 & -.00351 & $-.01264 * *$ & $.02240 * * *$ \\
\hline & $(.0026)$ & & & $(.00418)$ & $(.00307)$ & $(.00530)$ & $(.00652)$ \\
\hline \multirow[t]{2}{*}{ Contiguity } & & -.0086 & & -.01787 & -.00612 & $-.04166^{* *}$ & $.04282 * * *$ \\
\hline & & $(.0080)$ & & $(.01105)$ & $(.00661)$ & $(.01879)$ & $(.01467)$ \\
\hline \multirow[t]{2}{*}{ Same country } & & & $.0200 * * *$ & $.02254 * * *$ & .01062 & $.02859 * *$ & -.01357 \\
\hline & & & $(.0064)$ & $(.00803)$ & $(.00882)$ & $(.01115)$ & $(.01638)$ \\
\hline \multirow[t]{2}{*}{$\mathrm{y}_{\mathrm{j}, \mathrm{t}-1} * \operatorname{dist}_{\mathrm{ij}}$} & -.0041 & & & -.00298 & -.00465 & $-.01485 * *$ & $.02996 * * *$ \\
\hline & $(.0035)$ & & & $(.00550)$ & $(.00347)$ & $(.00698)$ & $(.00917)$ \\
\hline \multirow[t]{2}{*}{$\mathrm{y}_{\mathrm{j}, \mathrm{t}-1} *$ contiguity } & & -.0086 & & $-.02178 *$ & -.00961 & $-.049069 * *$ & $.04711 * * *$ \\
\hline & & $(.0092)$ & & $(.01322)$ & $(.00764)$ & $(.02205)$ & $(.01766)$ \\
\hline \multirow[t]{2}{*}{$\mathrm{y}_{\mathrm{j}, \mathrm{t}-1} *$ smentry } & & & $.0384 * * *$ & $.04333^{* * *}$ & $.01830 *$ & $.06719 * *$ & $-.06351 * *$ \\
\hline & & & $(.0121)$ & $(.01370)$ & $(.01059)$ & $(.02165)$ & $(.03064)$ \\
\hline \multirow[t]{2}{*}{ War i } & $-.3491 * * *$ & $-.3491 * * *$ & $-.3473 * * *$ & $-.34696 * * *$ & $-.33843 * * *$ & $-.27627 * * *$ & $-.43813^{* * *}$ \\
\hline & $(.0702)$ & $(.0702)$ & $(.0701)$ & $(.07000)$ & $(.01673)$ & $(.07389)$ & $(.10658)$ \\
\hline \multirow[t]{2}{*}{ War j } & .0040 & .0037 & $.0079 * * *$ & .00858 & .00509 & .01517 & $-.01043 * *$ \\
\hline & $(.0025)$ & $(.0024)$ & $(.0031)$ & $(.00320)$ & $(.00957)$ & $(.00544)$ & $(.00516)$ \\
\hline \multirow[t]{2}{*}{ Constant } & -.2100 & -.2370 & -.2130 & -.18558 & $-.13050 * * *$ & $.69133 * * *$ & $-2.2545 * * *$ \\
\hline & $(.1528)$ & $(.1479)$ & $(.1467)$ & $(.14919)$ & $(.02388)$ & $(.19890)$ & $(.28482)$ \\
\hline $\mathrm{R}^{2}$ & 0.6068 & 0.6068 & 0.6075 & 0.6079 & 0.4759 & 0.3598 & 0.8328 \\
\hline Observations & 12,705 & 12,705 & 12,705 & 12,705 & 12,224 & 12,705 & 13,000 \\
\hline PSUs & 580 & 580 & 580 & 580 & & 580 & 580 \\
\hline Countries & 29 & 29 & 29 & 29 & & 29 & 29 \\
\hline Years & 20 & 20 & 20 & 20 & & 20 & 20 \\
\hline Country_FE & $\mathrm{Y}$ & $\mathrm{Y}$ & $\mathrm{Y}$ & $\mathrm{Y}$ & $\mathrm{Y}$ & $\mathrm{Y}$ & $\mathrm{Y}$ \\
\hline Year_FE & $\mathrm{Y}$ & $\mathrm{Y}$ & $\mathrm{Y}$ & $\mathrm{Y}$ & $\mathrm{Y}$ & $\mathrm{Y}$ & $\mathrm{Y}$ \\
\hline Method & OLS & OLS & OLS & OLS & 2SLS & OLS & OLS \\
\hline
\end{tabular}

Standard errors in parentheses. * significant at $10 \% ;{ }^{* *}$ significant at $5 \% ; * * *$ significant at $1 \%$. All variables are in logs, except dummy variables. The dependent variable is the log-difference of the variable indicated in the column heading. 


\section{References}

Alesina, A., Drazen, A., 1991. Why are stabilizations delayed? American Economic Review $81,1170-1188$.

Ashworth, J., Heyndels, B., 1997. Politicians' preferences on local tax rates: An empirical analysis. European Journal of Political Economy 13, 479-502.

Baldwin, R., Taglioni, D., 2006. Gravity for dummies and dummies for gravity equations. Discussion paper 5850, Centre for Economic Policy Research, London.

Baliamoune-Lutz, M., 2009. Entrepreneurship and reforms in developing countries. Research paper 2009/04, UNU-Wider, Helsinki.

Bartz, K., Fuchs-Schündeln, N., 2012. The role of borders, languages and currencies as obstacles to labor market integration. Discussion paper 8987, Centre for Economic Policy Research, London.

Becker, S.O., Egger, P.H., Seidel, T., 2009. Common political culture: Evidence on regional corruption contagion. European Journal of Political Economy 25, 300-310.

Besley, T., Case, A., 1995. Vote-seeking, tax-setting, and yardstick competition. American Economic Review 85, 25-45.

Bodenstein, M., Ursprung, H., 2005. Political yardstick competition, economic integration, and constitutional choice in a federation: A numerical analysis of a contest success function model. Public Choice 124, 329-352.

Brezis, E.S., Verdier, T., 2003. Political institutions and economic reforms in Central and Eastern Europe: A snowball effect. Economic Systems 27, 289-311.

Brueckner, J.K., 2000. Welfare reform and race to the bottom: Theory and evidence. Southern Economic Journal 66, 505-25.

Campos, N.F., Horvath, R., 2006. Reform redux: Measurement, determinants and reversals. Discussion paper 2093, IZA, Bonn.

Cukierman, A., Tommasi, M., 1998. When does it take a Nixon to go to China? American Economic Review 88, 180-197.

Dewatripont, M., Roland, G., 1992a. The virtues of gradualism and legitimacy in the transition to market economy. Economic Journal 102, 291-300.

Dewatripont, M., Roland, G., 1992b. Economic reform and dynamic political constraints, Review of Economic Studies 59, 703-730.

Dewatripont, M., Roland, G., 1995. The design of reform packages under uncertainty. American Economic Review 85, 1207-1223.

Durlauf, S.N., 2004. Neighborhood effects. In: Henderson, J.V., Thisse, J.F. (Eds.), Handbook of regional and urban economics. Elsevier, Amsterdam, pp. 2173-2242.

Faber, G., Gerritse, M., 2012. Foreign determinants of local institutions: Spatial dependence and openness. European Journal of Political Economy 28, 54-63.

Gassebner, M., Gaston, N., Lamla, M., 2011. The inverse domino effect: Are economic reforms contagious? International Economic Review 52, 183-200.

Hellman, J.S., 1998. Winners take all: The politics of partial reform in post-communist transitions. World Politics 50, 203-234.

Holder, R., 2012. The political economics of the Arab Spring. Working paper 4023, CESifo, Munich.

Kelejian, H.H., Murrell, P., Shepotylo, O., 2013. Spatial spillovers in the development of 
institutions. Journal of Development Economics 101, 297-315.

Meseguer, C., 2006. Learning and economic policy choices. European Journal of Political Economy 22, 156-178.

Nickell, S., 1981. Bias in dynamic models with fixed effects. Econometrica 49, 1417-1426.

Salmon, P., 1987. Decentralization as an incentive scheme. Oxford Review of Economic Policy 3, 24-43.

Shleifer, A., 1985. A theory of yardstick competition. Rand Journal of Economics 16, 319327.

Wrede, M., 2001. Yardstick competition to tame the Leviathan. European Journal of Political Economy 17, 705-721. 